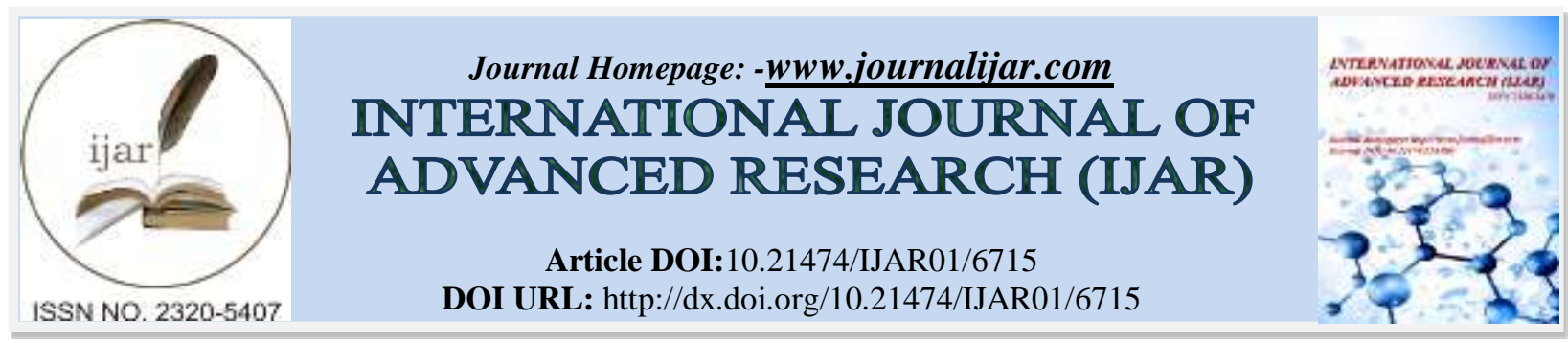

RESEARCH ARTICLE

\title{
INTRODUCTION OF EXOTIC BREEDS IN EXTENSIVE LIVESTOCK FARMING SYSTEM OF BURKINA FASO: ASSESSMENT AND PROSPECTS.
}

\section{Albert Soudré ${ }^{1}$, Moustapha Gréma ${ }^{2}$, Stéphane A. R. Tapsoba ${ }^{3}$, Moumouni Sanou ${ }^{3}$, Amadou Traoré ${ }^{3}$ and Hamidou Hamadou Tamboura ${ }^{3}$.}

1. Université Norbert Zongo, Unité de Formation et de Recherches en Sciences et Technologies (UFR/ST), BP 376 Koudougou, Burkina Faso.

2. Faculté des Sciences Agronomiques, Diffa University, BP 78, Diffa, Niger.

3. Institut de l'Environnement et de Recherches Agricoles (INERA)-Laboratoire de Biologie et Santé animales, 04 BP 8645 Ouagadougou 04 Burkina Faso.

\section{Manuscript Info}

(.........................

Manuscript History

Received: 10 January 2018

Final Accepted: 12 February 2018

Published: March 2018

Keywords:-

Burkina Faso, Sahel, native, exotic, cattle, breed, adaptation, productivity.

\section{Abstract}

A study on the situation of exotic cattle breeds introduced in Burkina Faso was conducted in the province of Soum (Djibo) located in the north of the country, a Sahel area of West Africa. The aim of the study was to i) assess the adaptation of exotic breeds with high productive potential in a difficult climatic context and ii) evaluate their productivity in comparison with the native breeds.

A participatory survey associated with field visits were conducted to assess the survival and adaptation abilities of exotic breeds and the crossbred offspring as well as their productive (growth and milk) and reproductive performances.

The study showed that cattle herds in the region included on one hand, pure breeds consisting of native (Fulani and Azawak) Zebus, Gir and Girolando breeds imported since 2004 from Brazil (30 cows and 10 bulls) and other breeds imported from Europe in the form of semen (Holstein, Montbeliard cattle, Tarentaise cattle and Alpine Brown cattle) and multipurpose breeds from various crosses.

The exotic animals were directly put within the farms under the direct management of the livestock breeders. All of them survived under the conditions of the Burkina Faso sahelian area apart from two dead animals recorded. At the time of the investigation, 160 individual animals (pure imported breeds and crossbred) were present in the province. The first heats of pure heifers of the exotics animals were observed at 12 to 14 months of age. The average calving interval was $14 \pm 2.3$ months for crossbred individuals. Birth weight was significantly higher in crossbreds Holstein x Girolando $(32.5 \mathrm{~kg})$ and Gir x Girolando (30.3kg) compared to local calves Azawak (20.5kg) and Fulani $(18.9 \mathrm{~kg})$. The average milk yield of the crossbred cows (with exotic genes) in 180 days of lactation was $1309.85 \mathrm{~kg}$ compared to $616.86 \mathrm{~kg}$ in the Azawak cow and $455.46 \mathrm{~kg}$ in the Fulani cow. These results command that appropriate measures should be taken by competent authorities for a rational management of these genetic resources in the province to ensure sustainable genetic improvement. 


\section{Introduction:-}

The genetic improvement of dairy cattle in Burkina Faso is getting more and more interest especially in peri-urban farms. Indeed, the volume of domestic milk production is very low in relation to the needs of the population despite the large numbers of ruminants: 8,072,420 cattle, 19 million small ruminants (ENEC II, 2004). National dairy production is based on the use of local breeds, which are highly adapted to difficult environmental conditions (poor pastures, scarcity of drinking water, disease resistance, low input use) due to the a capricious rainfall. Their milk production averages 2 to 3 liters of milk per day in $6-7$ months of lactation and 500 to 600 liters per lactation (Koanda, 1995 ; Boly et al., 2000). The deficit is covered through massive imports (more than 10 billion CFA francs in 2001 (MRA, 2001)) of milk and dairy products, which are already weighing heavily on the trade balance, as is also the case in Senegal, where the deficit reached 37 billion CFA francs in 2004 (Ba Diao et al., 2006). The inability of the national livestock to produce enough milk and dairy products is due to handicaps of various kinds, including health, diet and animal genetic material used (Mbogo, 1974 ; Toukou, 2001 ; Baker et al., 2002; Haile et al., 2002;; ENEC II, 2004; Gizaw et al., 2008; Mwai et al., 2015). In terms of health, the animal health situation in the Soum province was characterized by a low incidence of major animal diseases (Doulkoum and Paré, 2003, Soudré et al., 2012). In general apart from pasteurellosis, all other diseases occured sporadically in the herds.

Given the situation, the government of Burkina Faso has developed over the last decade, a policy to promote the milk sector. One of the major axes is the genetic improvement by crossbreeding with exotic bulls that perform better at the farm level in peri-urban areas and even in rural areas. The results of these crosses have been quite interesting with crossbreds producing about 12 liters of milk per day (Boly et al., 2000). Introductions of exotic cattle breeds in the Soum province began in 2001 with Azawak Zebu from Niger by the "Projet de Soutien à la Diffusion du Zébu Azawak (PSDZA)". Then there was the intervention of the "Projet de Développement de l'Elevage dans la province du Soum (PDES)", which introduced in 2004, 40 live cattle from Brazil (Gir and Girolando) and semen for artificial insemination (AI). The exotic animals were placed (sold) to 24 volunteer breeders in 3 departments (Aribinda, Baraboulé and Djibo) according to a loan system defined by PDES II. A set of specifications has been drawn up by mutual agreement between PDES II and the breeders, particularly on the management of the animals and the crossing system.

The government efforts aimed at designing genetic improvement strategies through adapted programs and schemes to promote a breeding that satisfies the following three objectives: (i) zootechnical performance; ii) economically profitable and iii) respectful of the environment.

The study aimed to assess the genetic improvement actions on the local zebu cattle in a sahelian context in order to possibly share this experience with other sahelian countries that might consider similar actions.

The specific objectives were: to assess the adaptation of exotic breeds with high productive potential in a difficult climatic context and to evaluate their productivity in comparison with the native breeds.

\section{Materials and methods:-}

\section{Biological material and breeding systems:-}

The biological material consists of live animals and semen. Live animals were represented by: the Sudanese Fulani Zebu, the Azawak Zebu from Niger introduced in the province from 2001 by PSDZA. The Brazilian breeds introduced from Brazil and set up by PDES II breeders, numbering 40 (Table 1), are represented by the Gir Zebu (10 males) and the Girolando taurine breed (30 females) and their offspring (Photo 1a, 1b, 1c, 1d).

Breeds introduced as semen were mainly represented by Holstein, Montbeliard cattle, Alpine Brown cattle and Tarentaise cattle.

A total of 219 cows were inseminated from 2007 to 2008 and 219 cows were inseminated in 2009. The distribution of semen used by locality per year is described in Table 2. 
Table 1:- Distribution of introduced Brazilian cattle by department

\begin{tabular}{|l|c|c|}
\hline \multirow{2}{*}{ Department } & \multicolumn{2}{|c|}{ Introduced animals } \\
\cline { 2 - 3 } & Gir (males) & Girolando (females) \\
\hline Aribinda & 03 & 08 \\
\hline Baraboulé & 01 & 03 \\
\hline Djibo & 06 & 19 \\
\hline Total & $\mathbf{1 0}$ & $\mathbf{3 0}$ \\
\hline
\end{tabular}

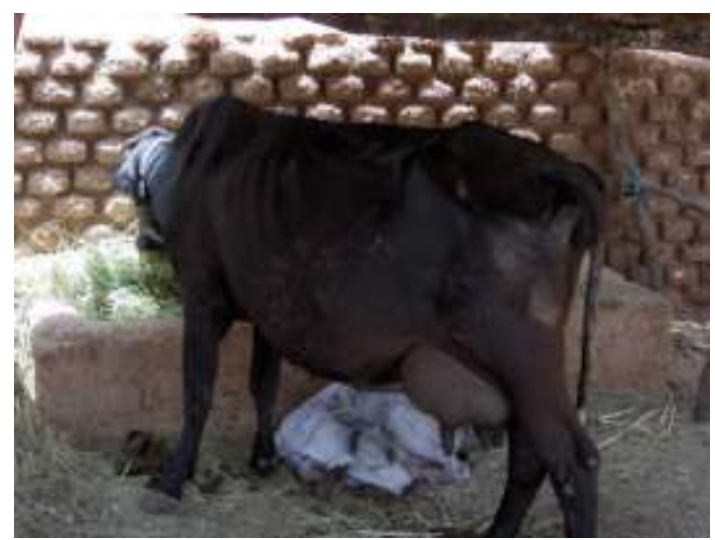

Picture 1a:- Girolando cow

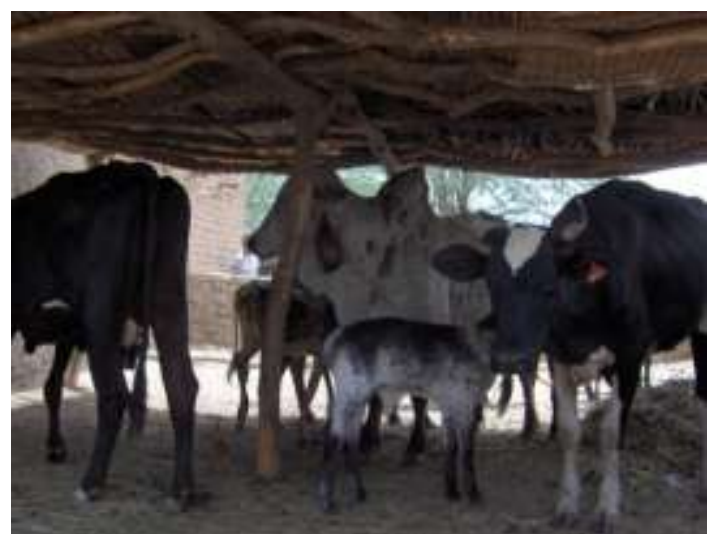

Picture 1b:- Gir Bull and crossbred calf Gir-Fulani Zebu

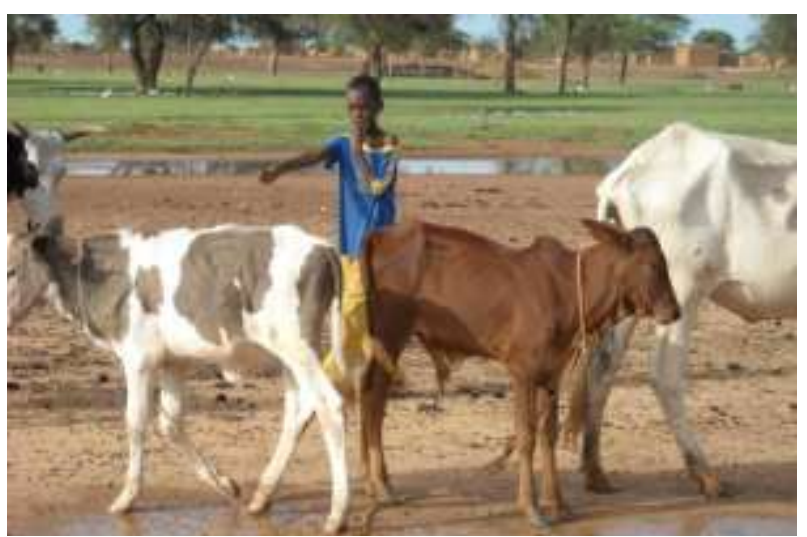

Picture 1c:- Crossbred calves Holstein X Fulani Zebu

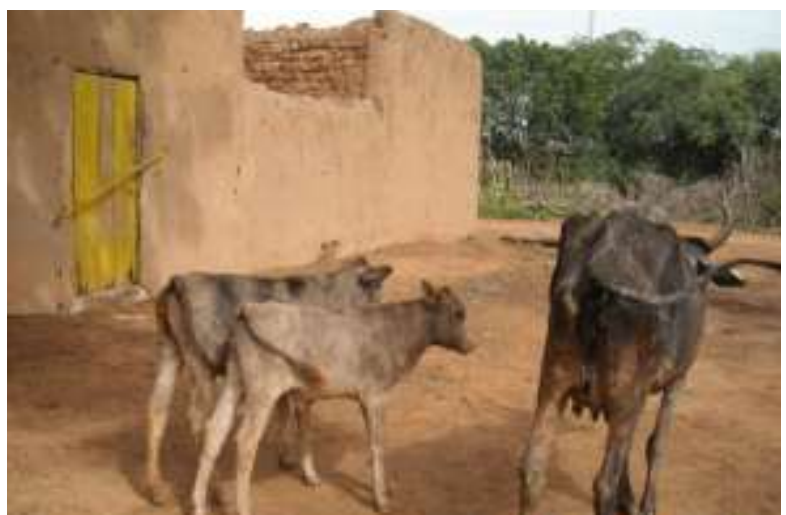

Picture 1d:- Crossbred twins of Alpine Brown X Fulani Zebu

Table 2:- Semen distribution by site per year.

\begin{tabular}{|l|l|l|l|}
\hline \multirow{2}{*}{ Localities } & \multicolumn{3}{|c|}{ Years/used semen } \\
\cline { 2 - 4 } & 2007 & 2008 & 2009 \\
\hline Borguiemdé & Holstein & Holstein & Gir \\
\hline Aribinda & Holstein and Gir & Gir & Gir and Alpine Brown \\
\hline Pétégoli & Holstein & Alpine Brown & \\
\hline Tongomayel & Holstein & Alpine Brown & \\
\hline Djibo & Holstein & Holstein & $\begin{array}{l}\text { Alpine Brown and } \\
\text { Montbeliard }\end{array}$ \\
\hline Kobawa & Holstein & & Gir and Alpine Brown \\
\hline Firguindi & Holstein & Holstein & \\
\hline Béléhédé & & Montbeliard & \\
\hline N'ganoua & & Holstein & \\
\hline Gaïk Ngoata & & Montbeliard & \\
\hline
\end{tabular}




\begin{tabular}{|l|l|l|l|}
\hline Liki & & Alpine Brown & Gir \\
\hline Gorguel & & Montbeliard & \\
\hline Baraboulé & & & Gir \\
\hline Pobé Mengao & & & Gir \\
\hline Kelbo & & & Gir \\
\hline
\end{tabular}

Breeding systems in the area were of traditional extensive type. The diet was based on natural pasture from 9am to $4 \mathrm{pm}$ and only the animals in production and the exotic breeds were receiving after grazing a supplement based on cotton cakes, wheat bran and licks.

In terms of health, the extension workers of the public service were responsible of applying treatments against major endemics diseases and intervening when needed on breeders' request.

\section{Participatory survey and data collection:-}

A participatory and exploratory survey was conducted among cattle breeders in the province of Soum from a formal questionnaire. These breeders were randomly selected by the supervisors of the provincial livestock resources service at the level of each municipality taking into account cattle breeding practices. The survey was conducted between late 2010 and early 2011. Collected data covered the following parameters: (i) production and reproduction, (ii) information on artificial insemination (breed and bull code, date of insemination, name of the operator, name of the breeder, code of the inseminated cow, etc.).

Production and reproduction data as well as those related to the adaptation and the situation of the exotic cattle were collected based on information recorded in the monitoring booklets and the breeders' statements during organized interviews. The adaptability of the exotic breeds was measured by the rectal temperature and respiratory rate of about thirty Brazilian cattle in hot weather (april - may), morbidity and survival in a context of endemic pathologies (hemorrhagic septicemia, contagious bovine pneumonia, gas gangrene infections, etc.).

Body weights at typical ages were collected on farms at birth, 30, 60 and 90 days at the same period.

\section{Identification and monitoring of animals:-}

The animals were identified with ear tags using 11 digits identification system including the place code, genotype, and year of birth of the animal.

\section{Data analysis:-}

Data recorded in sheets and follow-up booklets were used. Growing performance and reproduction results were analyzed using Statview 4.57 software. Differences between means were considered significant at $P<0,05$.

Rectal temperature data are presented as mean \pm standard deviation and compared to values found on other breeds (Kaboré et al., 2005).

\section{Results and discussions:-}

\section{Adaptation of crossing products:-}

The adaptability of exotic breeds introduced in the province of Soum was assessed climatically, ecologically and pathologically.

\section{Adaptation to ecology and local climate:-}

Adaptation of animals to climate and local ecology was assessed by rectal temperature, respiratory rate, and animal behavior (as reported by breeders).

Table 3 presents the results of 30 exotic cows (Girolando from Brazil) compared to Fulani Zebu cattle data from Kaboré et al. (2005) study.

Table 3:-Average values of rectal temperature and breathing rate of Girolando and Fulani breeds.

\begin{tabular}{|l|l|l|}
\hline & \multicolumn{2}{|c|}{ Breeds } \\
\hline Measured parameters & Girolando & Fulani Zebu (Kaboré et al., 2005) \\
\hline Rectal Temperature & $38,9 \pm 0,6^{\mathrm{a}}$ & $38,7 \pm 0,3^{\mathrm{a}}$ \\
\hline
\end{tabular}




\begin{tabular}{|l|l|l}
\hline Breathing rate & $32,8 \pm 1,6^{\mathrm{a}}$ & $30,7 \pm 2,3^{\mathrm{b}}$
\end{tabular}

Different letters in the same row stand for significant difference $(\mathrm{P}<0.05)$

The results showed a significant increase in breathing rate of the Girolando breed compared to the native Fulani Zebu.

Good adaptability to local climate was noted by breeders based on animal behavior in the province with however a slight difficulty at the beginning of the introductory period that persisted during the first month. Crossbred cattle performed better than pure breeds.

\section{Feeding behavior:-}

At the management level, exotic animals were conducted in the same way as local breeds without major difficulties. The reported difficulties were related to the high food consumption of the Gir and Girolando because of their very high body weight as reported also in Benin (Hounkpevi, 2005). These animals could consume 2 times more feed than local breeds and the water consumption is very high (more than 10 liters of water per day) according to the declarations of the breeders. Authors also reported that exotics and crossbreds require better feeding in terms of quality and quantity (Galukande, 2010 ; Kluszczynska, 2012; Getachew, 2016)

\section{Adaptation to environmental pathologies:-}

Pathologically, imported breeds performed well in their new environment. Common pathologies in the province have rarely been cited in interviews with breeders and officers of the provincial animal resources directorate.

The pathologies reported in Gir and Girolando were abscesses in the trough but they recovered very quickly after antibiotic therapy.

Seven cases of mortality have been reported in live exotic breeds since their introduction with various causes:

1. Swallowed foreign bodies (3 cases);

2. Poisoning due to sorghum young shoots ( 2 cases);

3. Milk fever (1 case);

4. Tuberculosis (1 case).

The exotic animals performed well and showed a good adaptability to the pathologies commonly encountered in the region as well as the local breeds.

\section{Appraisal of introduced animals and their crossbred offspring:- \\ Current situation of Gir and Girolando and their crossbred offspring:-}

The introduction of Gir and Girolando breeds in the Soum province was aimed at increasing milk production by crossbreeding with local breeds, which should lead to crossbred heifers according to a scheme provided by the project: use of the Gir breed as breeding stock for crossbreeding Girolando and local Zebu breeds (Figure 1). 


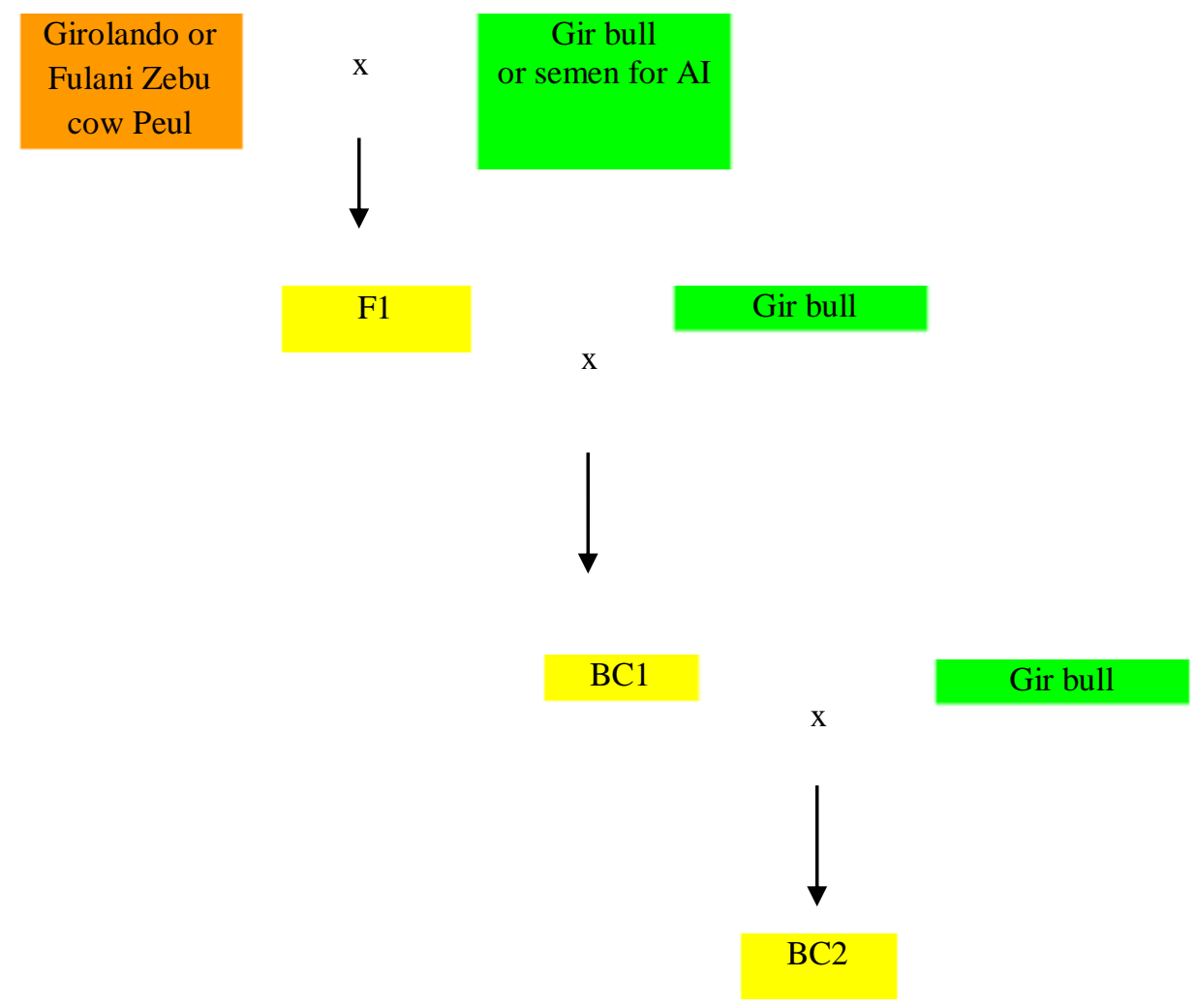

Figure 1:- Diagram of crossbreeding introduced by the PDES II $\mathrm{F} 1=1$ st generation of crossbreeding; $\mathrm{BC} 1(\mathrm{BC} 2)=1$ st $(2$ nd $)$ Back-cross

The first generation (F1) and crossbred (BC1) females were intended for milk production while the males were destined for butchery. However, some crosses that did not correspond to the one described in the diagram (Figure 1) had occurred at different places and were called undesired crosses. The situation of Brazilian breeds and their crossbreeds is recorded in Table 4.

Thirty-three out of 40 animals of Brazilian origin introduced into the province in 2004 were present at the study time. From the 40 animals, 7 died due to swallowed foreign body and food poisoning.

A total of 101 crossbred animals had been produced since the introduction of the said animals with 8\% of nondesired animals, which did not fit into the initial scheme of crossing thought by the project (Azawak x Girolando, Gir x Azawak and Fulani Zebu x Girolando). There were 50 F1 males, which represented almost 50\% of the crossbred population.

Table 4:- Situation of the Gir and Girolando of their offspring at the study time

\begin{tabular}{|c|c|c|c|c|c|c|c|c|c|c|c|c|c|}
\hline \multirow[t]{2}{*}{ Department } & \multirow[t]{2}{*}{ Gir } & \multirow[t]{2}{*}{ Girolando } & \multicolumn{2}{|c|}{ GGo1 } & \multicolumn{2}{|c|}{ GF1 } & \multicolumn{2}{|c|}{ AGo1 } & \multicolumn{2}{|c|}{ GA1 } & \multicolumn{2}{|c|}{ FG1 } & \multirow[t]{2}{*}{ Total } \\
\hline & & & M & $\mathrm{F}$ & M & $\mathrm{F}$ & M & $\mathrm{F}$ & $\mathrm{M}$ & $\mathrm{F}$ & $\mathrm{M}$ & $\mathrm{F}$ & \\
\hline Aribinda & 03 & 06 & 04 & 01 & 10 & 13 & 00 & 01 & 00 & 01 & 00 & 01 & 40 \\
\hline Baraboulé & 01 & 03 & 05 & 00 & 02 & 02 & 00 & 00 & 00 & 00 & 00 & 00 & 13 \\
\hline Djibo & 05 & 15 & 09 & 09 & 18 & 20 & 00 & 01 & 01 & 01 & 01 & 01 & 74 \\
\hline Total & 9 & 24 & 12 & 10 & 30 & 35 & 00 & 02 & 01 & 02 & 01 & 02 & 127 \\
\hline
\end{tabular}

GGo1: Gir-Girolando F1 ; GF1 : Gir- Foulani Zebu F1 ; AGo F1 : Azawak-Girolando F1 ; GA1 : Gir-Azawak F1; FGo1: Fulani Zebu-Girolando F1. 


\section{Situation of artificial insemination offspring:-}

Of the 219 cows inseminated between 2007 and 2008, the province of Soum had 45 offspring (24 males and 21 females). One death and 4 abortions were noted during the period. Other 218 cows were inseminated in 2009. The situation of artificial insemination offspring in the province since the beginning of the program was recorded as followed (data not shown): Holstein (12 males (M), 15 females (F)); Montbeliard cattle (6 M, 5 F); Alpine Brown cattle $(6 \mathrm{M}, 1 \mathrm{~F})$. These data were only about AI carried out in 2007 and 2008. The success rate of the AI was therefore $20.55 \%$, which was quite low.

\section{Animal productivity parameters:-}

The performances of the exotics introduced in the Soum province and their offspring were evaluated from breeding parameters, individual milk yield and weight at typical age. These parameters were compared with those of other breeds present in the area (Fulani Zebu and Azawak Zebu) at the study time.

\section{Reproductive performance:-}

The breeding parameters of exotic breeds and their crossbred offspring as well as those of local breeds are presented in Table 5 .

The calving interval was 420 days in crossbred animals, which is closed to the rate of one calf per cow per year. The values found in this study were similar to those noted in Senegal for exotic breeds and Gobra zebu (Kouamo et al., 2009). They were also closed to those reported in Senegal by Sow and Diop (1996) for Jersey cattle (428 days) and much lower than Holstein introduced in Ghana (480 days) (Osei et al., 1991). The calving intervals observed in our case were however higher than the values reported in Morocco (391 days) for Friesian cattle (Srairi and Kessab, 1998). First generation crosses (local with exotic dairy breeds) are considered to have more efficient reproductive performance than local cows in terms of earlier age at first calving and shorter calving intervals (Ayenew et al.,2008; Galukande, 2010). The indigenous cattle generally have a long calving interval (Ouédraogo, 2014; Grema, 2018). This is may be due to poor feeding conditions and health management in the rural areas.

Table 5:- Reproductive parameters of exotic breeds, crossbreds and local breeds in the Province of Soum

\begin{tabular}{|l|l|l|l|}
\hline Parameters & Exotic breeds & Crossbreds & Fulani Zebu \\
\hline First heat (months) & $11-12$ & $10-15$ & $28-35$ \\
\hline Age at first calving (months) & $18-24$ & $20-28$ & $48-60$ \\
\hline Calving interval (days) & 400 & 420 & $359-480$ \\
\hline
\end{tabular}

\section{Milk and meat performances:-}

The production parameters of the exotic animals were evaluated using birth weights and weights at typical age, as well as milk yield. These values were compared with those collected from other breeds living in the same area at the study time.

The weight at birth and the weight at typical age of Gir and Girolando genotypes and other local and / or exotic breeds are shown in Table 6.

Weights at birth showed significantly higher values for Holstein-Girolando (HGo) crossbred animals (32.49kg), which corresponded to genotypes with $75 \%$ Holstein blood. They were followed by crossbreds between Gir and Girolando (GGo) (30.29 kg) and crosses between Gir- Fulani Zebu (GF) (21.96 kg). Azawak- Fulani Zebu (AF) $(20.6 \mathrm{~kg})$ crossbred animals had lower birth weight but higher than the values recorded for Azawak (AA) calves $(20.5 \mathrm{~kg})$ and Fulani Zebu (FF) calves $(18.9 \mathrm{~kg})$. The difference between birth weights of AA and AF genotypes was not significant. However, there was a significant difference between the birth weights of the first three genotypes (GGo, GF and HGo) and those of the last 3 genotypes (AA, AF and FF) at $\mathrm{P}<0.05$, as well as between GGo genotypes, GF and HGo. The birth weight of local breeds was less than the birth weight of Sunandini breed in India (28.3 kg) reported by Singh (2016).

The weight values at birth found in crossbred individuals GF $(21.96 \mathrm{~kg})$ are higher than the values of $18.91 \mathrm{~kg}$ reported by Hounkpevi (2005) on crossed Gir x Borgou in Benin, which were, however, comparable to the Fulani zebus of our study. Weightat typical age analysis showed faster growth of GGo genotypes compared to other crossbreeding animals despite the higher birth weight of HGo crosses. Indeed, these animals reached an average of $71.49 \mathrm{~kg}$ after 3 months of age, compared to 67.49 and $58.49 \mathrm{~kg}$ respectively for the HGo and GF genotypes. 
Animals of genotype AA had weight at 3 months $(54.8 \mathrm{~kg})$ significantly lower than the 1 st group but higher than those of genotype AF $(48.8 \mathrm{~kg})$ and FF $(48.5 \mathrm{~kg})$ at $\mathrm{P}<0.05$. These observations indicated not only that Gir and Girolando were multipurpose animals but he management of the led breeders was also good. To this must be added the good adaptability of these breeds and their offspring.

The dairy production analysis was carried out using data from monitoring sheets of 9 Girolando cows. The crossbred females were not yet in production. The analysed parameters were evaluated over a period of 6 months (180 days) in order to compare them with those of local cows in the region.

Table 6:- Weight at birth and weight at typical age (kg) of crossbreds and local animals.

\begin{tabular}{|c|c|c|c|c|c|c|}
\hline \multirow[t]{2}{*}{ Ages } & \multicolumn{6}{|c|}{ Weight (mean \pm standard deviation) in $\mathrm{kg}$} \\
\hline & GGo1 (12) & GF1 (10) & HGo1 (15) & AA (30) & $\mathrm{AF}(30)$ & FF (30) \\
\hline At birth & $30.29 \pm 3.44$ & $21.96 \pm 0.70$ & $32.49 \pm 0.4$ & $20.5 \pm 3.4$ & $20.6 \pm 3.7$ & $18.9 \pm 3.4$ \\
\hline 30 days & $48.40 \pm 1.14$ & $31.99 \pm 0.44$ & $43.66 \pm 0.24$ & $31.0 \pm 10.0$ & $30.2 \pm 0.8$ & $\mathrm{Na}$ \\
\hline 60 days & $\mathrm{Na}$ & $\mathrm{Na}$ & $\mathrm{Na}$ & $48.6 \pm 9.17$ & $47.7 \pm 8.4$ & $\mathrm{Na}$ \\
\hline 90 days & $71.49 \pm 1.12$ & $58.49 \pm 0.5$ & $67.49 \pm 0.5$ & $54.8 \pm 22.9$ & $48.8 \pm 14.2$ & $48.5 \pm 4.3$ \\
\hline
\end{tabular}

GGo1 : Gir x Girolando F1 ; GF1 : Gir x Fulani Zebul F1; HGo1 : Holstein x Girolando F1; AA : Azawak ; AF : Azawak x Fulani Zebu ; FF : Fulani Zebu ; Na : non available ; (12) : sample size

\section{Lactation length:-}

Girolando cows which were in production were milked manually in all the farms managed by PDES II. Milking was done twice (morning and evening) by a milker who was either a member of the family or a herdsman. Milking was made in the presence of the calf. The collected milk had a dual function: one part was used for home consumption and the other part was sold as raw milk or after processing. The income was used to meet the expenses of the farm and the needs of the family (health, school fees, etc.). Of the total number of cows surveyed, three cows had an average lactation length of $366.6 \pm 47.6$ days, which was longer than the normal 10-month period in order to prepare the next lactation (Lefebvre, 2009). Two cows (2) were still milking at $520.8 \pm 19.8$ days of lactation. These results revealed that cows were still milking beyond 305 days of lactation, usual lactation length in dairy cow. But Singh (2016) also reported 322 days for lactation length with various Brown Swiss crossbred in India.

\section{Milk yield of Girolando cows in the Soum province:-}

The daily milk yield was used to analyse the parameters related to dairy production of Girolando cows under PDES II project. The milk quantities were regulated by the breeders according to the market and do not take into account the intake of the calf.

The milk yield was estimated at 1271.71 in 6 months lactation (180 days) with an average daily milk yield of $7.1 \pm$ 1.9 1. The average daily milk yield of the best breeder calculated over the 180 days of lactation was 9.41 . This average is higher than what have been recorded in Butan Hostein Friesian x Sahiwal (Dhillon and Jain, 1977). Our results were higher than those of Azawak Zebu cows (598.9 1) and Fulani breeds (442.2 1) reported by INERA (1999) recorded in the province of Soum in 186 days of lactation. The milk yield was higher than those of the local breed and lower than the values reported on a state farm in Benin for exotic Girolando cows (10 to 121 per day). The milk yield of the first crossbred generation (F1) is more than twice as the milk yield of local dairy cattle breed. F1 brings the highest economic returns under poor feeding conditions (Mc Dowell et al., 1996). However, production of crossbred females Girolando x Borgou (6 to 7 l) was lower than that of a Girolando in the sahelian region of Burkina Faso (Dossou et al., 2004). Since dairy production is highly dependent on feed (Idrissou, 2004), cows on station, as it was in Benin, have benefited from better management and feeding conditions than the Girolando bred in the Soum province. Figure 2 shows the lactation curve of Girolando dairy cows in the province of Soum.

The evolution of milk yield began with an average daily production of 7.11 followed by a peak of lactation in the second month with a maximum daily milk yield estimated at 9.31 and a drop in the sixth month with an average production of $6.71 \mathrm{a}$ day. 
Milk yield

(l/day)

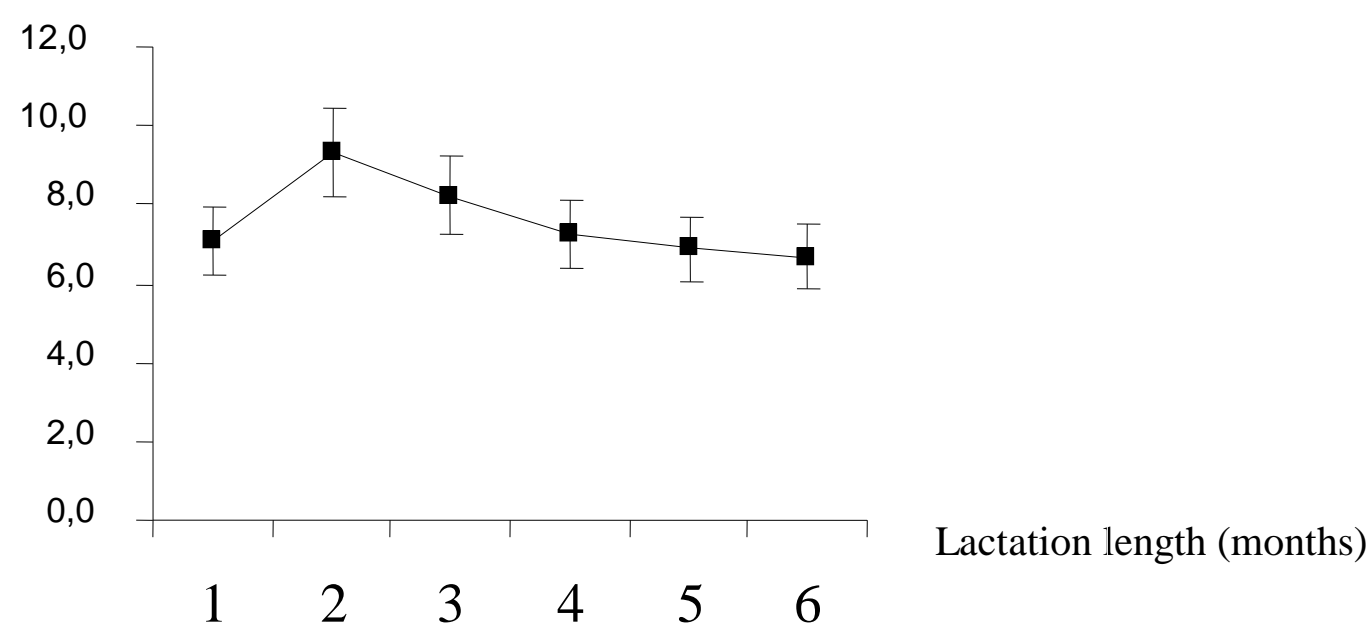

Figure 2:- Lactation curve of Girolando cows in the province of Soum

\section{Conclusion:-}

An analysis of the situation of animal genetic resources and their capacity to adapt in the province of Soum highlighted two essential aspects: i) a great diversity of animal genetic resources was present in the province of Soum. In addition to the existing local breeds (Fulani Zebu, Azawak Zebu), PDES II introduced taurine breed (Girolando) and alive Zebu of Brazilian origin. These individuals have been crossbred (GGol) with the local breeds and produced offspring (F1 and back-cross). Another type of introduction was done through AI on local females and exotic breeds (Gir and Girolando). The used semen were Holstein, Montbeliard cattle and Alpine Brown cattle. ii) good adaptability of introduced breeds. These individuals supported very well the sanitary and climatic conditions of their environment of reception, as evidenced by the productive and reproductive performances, but especially the reduced mortalities compared to data of other regions of the country (Fada). At the time of the study, more than 800 exotic offspring (pure and crossbreeds) were present in the province. It may result in indiscriminate cross-breeding, which will undoubtedly pose management problems in order to preserve local genetic resources, avoid inbreeding and genetic disorders in the future.

Appropriate measures must be undertaken by the authorities of the Ministry of Livestock Resources (MRA) to prevent such a situation and above all, to remain in control of the process of creating genetic progress in the region. This will involve i) putting in place a breeding strategy in order to perpetuate the gains and preserve the genetic diversity; ii) train the actors to implement the breeding strategy.

\section{Acknowledgements:-}

This work has been financially supported by 'Projet de Développement de l'Elevage dans la province du Soum (PDES)-Phase II" and the International Atomic Energy Agency through project BKF / 5/008. 


\section{References:-}

1. Ayenew A. Y., Zollitsch W., Wurzinger M., Tegegne A. (2008): Characterization and analysis of the urban and peri-urban dairy production systems in the North western Ethiopian highlands. PhD thesis. University of Natural Resources and Applied Life Sciences, Vienna, Austria.

2. Ba Diao M., Dieng A., Seck M.M., Ngomibé R.C. (2006): Pratiques alimentaires et productivité des femelles laitières en zone périurbaines de Dakar. Rev. Elev. Med. Vet. Pays Trop. 59 (1-4) :43-49.

3. Baker R. L., Mugambi J. M., Audho J. O., Carles A. B., Thorpe W. (2002): Comparison of Red Maasai and Dorper sheep for resistance to gastro-intestinal nematode parasites, productivity and efficiency in a mid and a semi-arid environment in Kenya In: Proceedings of the 7th World Congress on Genetics Applied to Livestock Production, 18-23 August 2002. Montpellier France 31:639-642.

4. Boly H., Somé S. S., Musabyimana J., Sawadogo L., Leroy P. (2000): Comparaison de la production laitière des zébus azawak et de leurs produits de croisement avec les taurins européens (Burkina Faso). J. Agricult. Environ. Int. develop. 95 (2/3): 187-198.

5. Dhillon J. S., Jain A. K. (1977): Comparison of Sahiwal and different grades of Holstein Friesian $\times$ Sahiwal crossbreds for efficiency of milk production. Indian J Dairy Sci 30: 214-217.

6. Dossou J., Hounzangbé-Adoté Sylvie, Soulé H. (2004): Production et transformation du lait frais en fromage Peulh au Bénin : Guide de bonnes pratiques. Université Abomey-Calavi, Faculté des Sciences Agronomiques, $33 \mathrm{p}$.

7. Doulkoum B., Paré M. (2003): Epidémiologies des principales maladies au Burkina Faso. In : Intensification des productions animales et pathologies associées. Communications présentées aux Journées de santé animales à Bobo-Dioulasso, 22 - 24 mai 2003. p. 12

8. Enquête Nationale sur l'Effectif du Cheptef (ENEC) II (2004): Deuxième enquête nationale sur les effectifs du cheptel, Burkina Faso Tome II, 86 p.

9. Galukande G. E. (2010): Comparison of production systems with purebred Ankole vs. crossbred AnkoleFriesian animals on-farm using a combined cross-sectional and longitudinal approach (Kiruhura District of Uganda). PhD Thesis. University of Natural Resources and Applied Life Sciences, Vienna, Austria.

10. Getachew T., Haile A., Wurzinger M., Rischkowsky B., Gizaw S., Abebe A. Sölkner J. (2016): Review of sheep crossbreeding based on exotic sires and among indigenous breeds in the tropics: An Ethiopian perspective. Afr. J. Agric. Res. 11(11): 901-911. DOI: 10.5897/AJAR2013.10626

11. Gizaw S., Komen H., Hanotte O., Van Arendonk J. A. M. (2008): Indigenous sheep resources of Ethiopia: types, production systems and farmers preferences. AGRI 43:25-39

12. Grema M. (2018): Caractérisation de la race bovine Kouri du Niger à l'aide d'indices morpho-biométriques et du polymorphisme des marqueurs microsatellites. Thèse de Doctorat unique. Université Abdou Moumouni, Niger. $142 \mathrm{p}$.

13. Haile A., Tembely S., Anindo D., Mukasa-Mugerwa E., Rege J. E., Yami A., Baker R. (2002): Effects of breed and dietary protein supplementation on the responses to gastrointestinal nematode infections in Ethiopian sheep. Small. Rumin. Res. 44:247-261.

14. Hounkpevi D.A. (2005): Elevage et amélioration génétique de la croissance des bovins Borgou de la ferme de l'Okpara en république du bénin. Mémoire présenté en vue de l'obtention du Diplôme d'Etudes Spécialisées en Gestion des Ressources Animales et Végétales en Milieux Tropicaux. Filière : Production Animale, 89 p.

15. Idrissou N.D. (2004): Amélioration intégrée de la production laitière de la vache Borgou au Bénin. Mémoire du Diplôme d'Etude Spécialisées en gestion des ressources animales et végétales en milieux tropicaux. Université de Liège et Gembloux. 120 p.

16. Institut de l'Environnement et de Recherches Agricoles (INERA). (1999): La filière lait au Burkina Faso : Etude-bilan, Version définitive. Ouagadougou : DPA. 68 p.

17. Kaboré A., Tamboura H.Hamidou, Diarra S., Bayala B., Traoré A., Belem A.M.G. (2005): Influence des facteurs climatiques sur les zébus laitiers de race Azawak et Peul soudanien en élevage périurbain à Ouagadougou (Burkina Faso). Cam. J. Exp. Biol. 1 (2), 62-70.

18. Kluszczynska M. (2012): Crossbreeding strategies for dairy production: Introduction, development and impact on smallholders in North Gondar, Ethiopia. Master thesis. University of Natural Resources and Life Sciences

19. Koanda S. (1995): Etude des systèmes d'élevage et de la production laitière bovine dans le terroir de Sambonay. Mémoire de fin d'étude : IDR. Université de Ouagadougou. 95 pages.

20. Kouamo J., Sow A., Leye A., Sawadogo G.J., et G. A. Ouédraogo G. A. (2009): Amélioration des performances de production et de reproduction des bovins par l'utilisation de l'insémination artificielle en Afrique Subsaharienne et au Sénégal en particulier : état des lieux et perspectives. Rév. Afr. Santé Prod. Anim, 7 (3-4), 139-148. 
21. Lefebvre D. (2009): D’une lactation à l'autre : pour une transition réussie. 33ème symposium sur les bovins laitiers, $39 \mathrm{p}$.

22. Mbogo D.E. (1974): Improvement of animal productivity in the tropics through artificial insemination. In : J.K. Loosli, V.K. Oyenuga and G.M. Badutunde (Editors), Animal production in the tropics. Heinemenn Educationnal Books (Nigeria) Limited, Ibadan.

23. McDowell, R. E., Wilk, J. C., Talbott, C. W. (1996): Economic Viability of Crosses and Bos taurus and Bos indicus for Dairying in Warm Climates. Journal of Dairy Science. 79 (7), 1291-1303.

24. Ministère des Ressources Animales (MRA). (2001): Statistiques du secteur de l'élevage au Burkina Faso. Ouagadougou : ENEC, $86 \mathrm{p}$.

25. Mwai O., Hanotte O., Kwon Y.-J., and Cho S. (2015): African Indigenous Cattle: Unique Genetic Resources in a Rapidly Changing World. Asian Australas. J. Anim. Sci. 28 (7) : 911-921.

26. Osei S.A., Effah-Baah K., Karikari P. (1991): The reproductive performance of Friesian cattle bred in the hot humid forest zone of Ghana. Anim. Genet. Res., 68: 490-497.

27. Singh C.V. (2016): Cross-breeding in Cattle for Milk Production: Achievements, Challenges and Opportunities in India-A Review. Adv. Dairy Res. 4:3 http://dx.doi.org/10.4172/2329-888X.1000158

28. Ouédraogo B. (2014): Production laitière dans les noyaux de Ouagadougou et de Komsilga : Etats des lieux et rentabilité. Mémoire d'ingénieur, Université Polytechnique de Bobo-Dioulasso, 86p.

29. Soudré A., Ouédraogo-Koné S., Wurzinger M., Müller S.,, Hanotte O., Ouédraogo A. G., Sölkner J. (2012): Trypanosomosis: a priority disease in tsetse-challenged areas of Burkina Faso. Trop. Anim. Health. Prod. DOI 10.1007/s11250-012-0248-4

30. Sow M.A., Diop P.E.H. (1996): Place du système d'élevage intensif dans la production du lait au Sénégal ; exemple de la Société alimentaire (Soca). In : Diop P.E.H., Mazouz A., éds, Reproduction et production laitière. Paris, France, Aupelf-Uref, p. 75-80. (Coll. Universités francophones).

31. Srairi M.T., Kessab B. (1998): Performances et modalités de production laitière dans six étables spécialisées au Maroc. Prod. Anim., $11: 321-326$.

32. Toukou T. M. (2001): Caractérisation et stratégies d'amélioration des fermes laitières semi-intensives périurbaines : cas de Ouagadougou. Mémoire de fin d'études IDR, Option Elevage. Université Polytechnique de Bobo-Dioulasso, $66 \mathrm{p}$. 